\title{
Erratum to: Influence of frequency content and amplitude of input motion in DSSI investigated by shaking table tests
}

Giovanni Biondi • Maria Rossella Massimino •

Michele Maugeri

Published online: 30 January 2015

C) Springer Science+Business Media Dordrecht 2015

\section{Erratum to: Bull Earthquake Eng DOI 10.1007/s10518-014-9696-8}

Because of a mistake during the editorial process this paper was published under the title:

Experimental study in the shaking table of the input motion characteristics in the dynamic SSI of a SDOF model

It should be:

Influence of frequency content and amplitude of input motion in DSSI investigated by shaking table tests

The online version of the original article can be found under doi:10.1007/s10518-014-9696-8.

G. Biondi

University of Messina, Contrada di Dio, 98166 S. Agata, Messina, Italy

e-mail: gbiondi@unime.it

M. R. Massimino $(\varangle) \cdot$ M. Maugeri

Department of Civil and Environmental Engineering, University of Catania,

Viale Andrea Doria 6, 95125 Catania, Italy

e-mail:mmassimi@dica.unict.it

M. Maugeri

e-mail: mmaugeri@dica.unict.it 